\title{
Flood Chronology of the Carson River Basin, California and Nevada Web Site
}

As new areas are developed to accommodate growth, communities are increasingly faced with the need to develop in flood-prone areas. Current efforts by the State of Nevada Floodplain Management Program, Nevada Division of Water Resources (NDWR), to support the Federal Emergency Management Agency's (FEMA) Map Modernization program, have been to act as a point of contact at the State level in communicating mapping needs for Nevada communities. In conjunction with floodplain mapping, NDWR has identified the task of compiling floodhazard information in a format accessible and understandable to the general public and Federal, State, regional, and local agencies. The Nevada Floodplain Management Program considers it essential to make historical flood information publicly available, particularly for river basins with significant current and future population growth.

The U.S. Geological Survey with the support of FEMA through NDWR's Floodplain Management Program has developed a web site to make historic flood information for the Carson River Basin publicly available. The focus of the web site is on existing data, both measured and estimated, and for flood events prior to streamflow monitoring. The web site contains information to help the general public in understanding the extent and frequency of flood hazards and risks in the Carson River Basin. The web site is available at

\section{http://nevada.usgs.gov/crfld/}

Information on this web site may be viewed in several ways:

By specific flood event: Events can be viewed by date, river reach (section of the river), or county. Available information may include photographs, video clips, floodfrequency analyses, meteorological data, narratives, streamflow data, and links to related web sites.

Floods included in the web site

\begin{tabular}{|c|c|c|}
\hline Tew Year's 2006 & May 1956 & ary 1904 \\
\hline January 1997 & December 1955 & March 1890 \\
\hline July 1994 & November 1950 & January 1886 \\
\hline February 1986 & January 1943 & July 1875 \\
\hline June 1983 & March 1938 & January 1875 \\
\hline February 1982 & December 1937 & January 1874 \\
\hline Janua & $\mathrm{Ma}$ & \\
\hline May & January 1914 & January 1862 \\
\hline Decen & $\mathrm{Jul}$ & mbe \\
\hline Febru & January 190 & December \\
\hline & & \\
\hline & & \\
\hline
\end{tabular}

By specific area: Areas can be viewed on maps which show the extent of river reaches and county boundaries. The county pages include zoning or land-use maps that show locations of specific events.

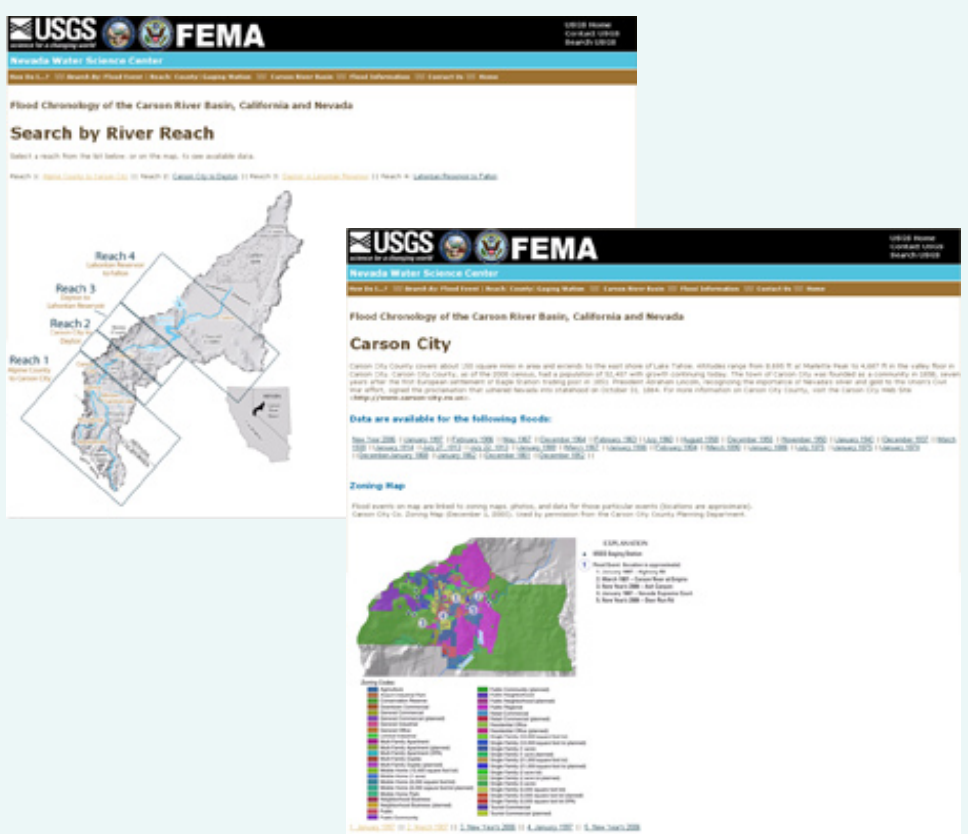

By gaging station: Gaging stations can be selected from the gaging-station map or by selecting a flood event, county, or river reach. Available hydrologic information includes annual peak flows, flood frequencies, and links to flood maps.

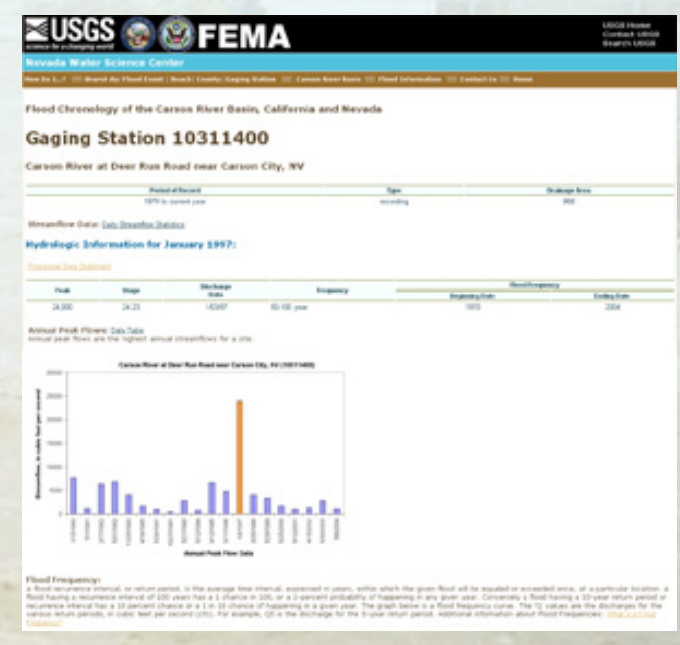




\section{Carson River Basin}

The Carson River Basin covers about 4,000 square miles in west-central Nevada and eastern California, from the eastern slopes of the Sierra Nevada in Alpine County, Calif., to the Carson Sink in Churchill County, Nev. The highest altitude in the basin is about 11,000 feet in the Sierra Nevada dropping to just under 4,000 feet above sea level near the Carson Sink.

Annual precipitation amounts vary from more than 55 inches at the upper altitudes to less than 5 inches at the lowest altitudes. At the upper altitudes, the snowpack accumulates during December through March when most precipitation falls as snow. Snowmelt provides most of the tributary and main-channel Carson River streamflow.

\section{Flooding}

Flooding, whether localized or basinwide, is a common phenomenon in the Carson River Basin. Three main types of flooding occur in the Basin:

\section{Main Channel Flooding}

Main-channel floods in the basin result from rain on the mountain snowpack which contributes to rapid snowmelt. As flow in the Carson River increases due to rapid snowmelt in the mountains, the channel overflows and floods adjacent areas known as floodplains (relatively smooth land bordering rivers that flood at time of high water). Because the Carson Valley is a broad floodplain, flooding can be widespread.

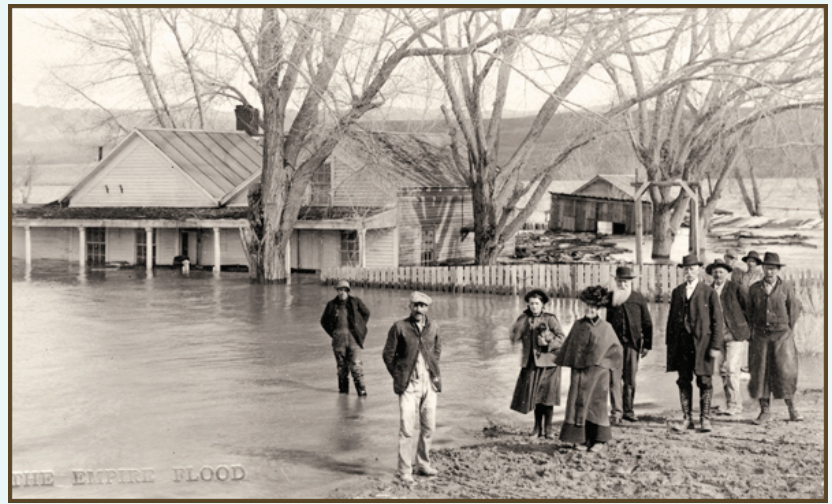

Main-channel flooding at the Hoover Hotel, Dayton, Nev., 1906. Photograph courtesy of the University of Nevada, Reno, Special Collection.

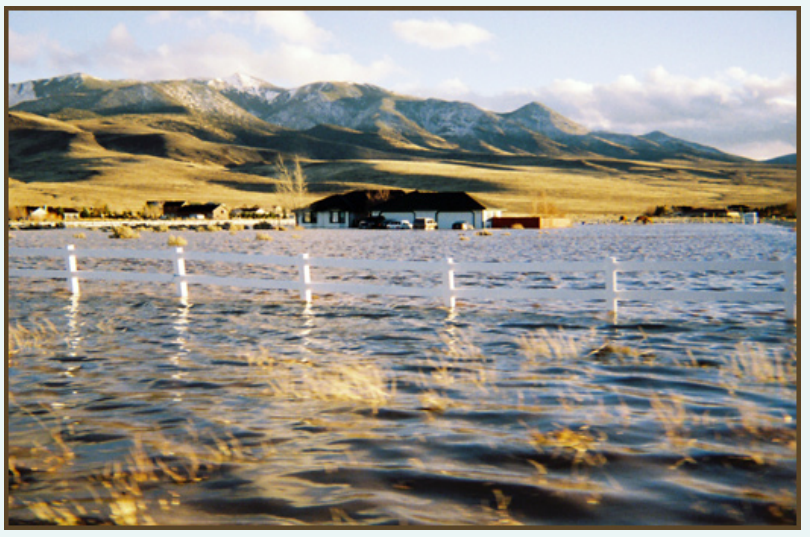

Localized flooding near Dayton Valley Road, Dayton, Nev., 2006.

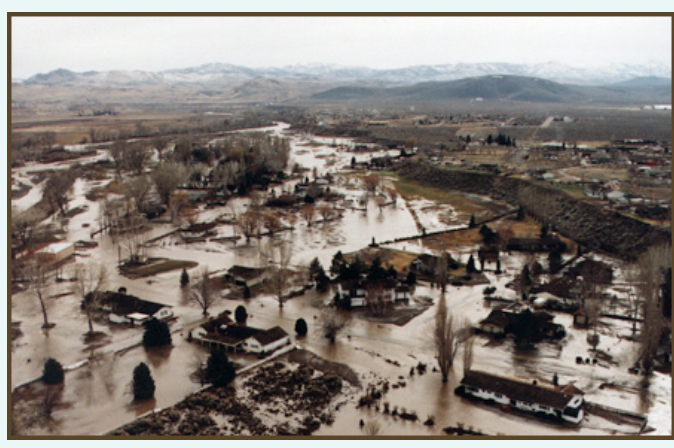

Main-channel flooding in the Carson Valley. Photograph by Rick Johnston, Nevada Department of Transportation.

\section{Localized Flooding}

Localized flooding (also known as flash flooding) results from intense rainfall during summer thunderstorms and typically occurs on alluvial-fan surfaces (gently sloping, fan-shaped landforms common at the base of mountain ranges). Localized flooding is characterized by high-velocity flows, erosion, sediment transport and deposition, and unpredictable flow paths. The risks from this type of flooding increase as development continues on flash-flood prone surfaces such as the east side of the Carson Valley and at the base of the Pine Nut Mountains in Dayton.

\section{Debris Flows}

Debris flows are the result of water from intense rainfall or rapid snowmelt mixing with sediment to become a slurry similar to wet concrete. In steep canyons (for example, the east slope of the Carson Range), debris flows can reach high velocities, transport large boulders, and cause catastrophic damage from impact or burial.

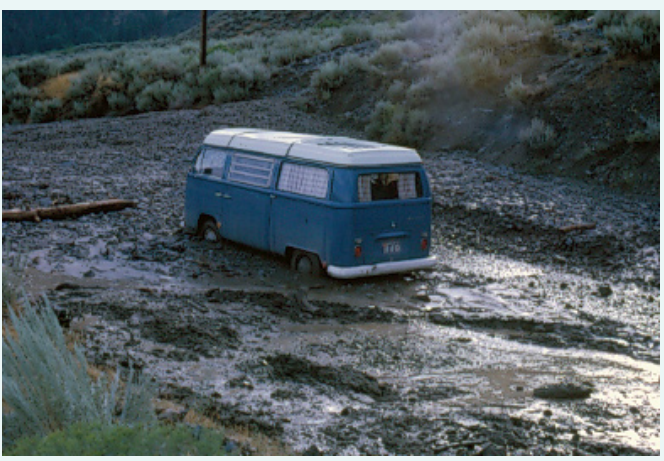

Volkswagon bus trapped in mudflow south of Genoa, 1971. Photograph by Pat Glancy, USGS retired.

Additional information about the Carson River Basin, this web site, as well as an explanation of terms is available at http://nevada.usgs.gov/crfld/

- Anne E. Jeton

For more information, please contact:

Anne Jeton

USGS Nevada Water Science Center

2730 N. Deer Run Rd.

Phone: (775) 887-7628

Carson City, NV $89701 \quad$ Email: aejeton@usgs.gov 